\title{
THE ROLE OF THE TRANSPORT SECTOR IN THE NEW PARTNERSHIP FOR AFRICA'S DEVELOPMENT (NEPAD)
}

\author{
I.N. MOUCHILI \\ G.C. PRINSLOO \\ gerriep@uj.ac.za \\ University of Johannesburg
}

\begin{abstract}
For many years Africa has presented a gloomy socio-economic picture. The problems Africa faces are so complex and interlinked that a holistic approach is needed to address the issues. Africa is increasingly being marginalised from world development. It accounts for only about $2 \%$ of the world total economic exchanges (UNECA, 2000). The New Partnership for Africa's Development (NEPAD) is an initiative by African leaders to inspire political stability and address shortages in infrastructure, education and health in an attempt to end misery across Africa and launch its sustainable development.

Inadequate infrastructure is a critical obstacle to intra-African trade and to the competitiveness of African products in international markets. Transport can facilitate the flow of people, ideas and technology. Bridging the transport infrastructure gap is therefore an important factor in unlocking the human and economic potential of the continent. NEPAD aims to coordinate and channel regionally fragmented efforts into one core long-term vision for the continent. NEPAD cannot work if there is too much high level strategic regional focus with little involvement of civil society, specific requirements and needs of African countries, and the private sector. It should develop some general high-level objectives and strategies related to transport operations and infrastructure, such as simplifying and harmonising transport regulations, deregulating the air industry and implementing the Yamoussoukro decisions, and focusing investments on transport corridors (road or rail).
\end{abstract}

\section{INTRODUCTION AND BACKGROUND}

For many years Africa, the poorest continent in the world, has presented a gloomy socioeconomic picture. The problems Africa faces are so complex and interlinked that a holistic approach is needed to address the issues. Africa is increasingly being marginalised from world development. It accounts for only about $2 \%$ of the world total economic exchanges (UNECA, 2000).

After years of solid growth during the 1970s, Africa's economic performance deteriorated during the 1980s and the early 1990s, which generated widespread pessimism about its 
future. Table 1 below shows the average annual Gross Domestic Product (GDP) growth in Africa for the period 1965-1999.

Table 1: Average annual GDP growth in Africa, 1965-1999 (percentage)

\begin{tabular}{|l|c|c|c|c|}
\hline & $\mathbf{1 9 6 5 - 6 9}$ & $\mathbf{1 9 7 0 - 7 9}$ & $\mathbf{1 9 8 0 - 8 9}$ & $\mathbf{1 9 9 0 - 1 9 9 9}$ \\
\hline Africa & 4.5 & 4.2 & 2.5 & 2.3 \\
\hline North Africa & 5.3 & 6.7 & 4.2 & 3.1 \\
\hline Sub-Saharan Africa (SSA) & 2.4 & 4.0 & 2.1 & 2.4 \\
\hline SSA including South Africa & 4.2 & 3.3 & 1.7 & 2.0 \\
\hline SSA excluding Nigeria & 3.5 & 3.9 & 2.5 & 2.3 \\
\hline
\end{tabular}

Source: UNCTAD, 2001:4

The average economic growth of 2.3 per cent in the 1990s remains well below the millennium targets of 7 per cent per annum that is necessary to halve poverty on the continent by 2015 . At its current rate of GDP growth, Africa is unlikely to achieve that target.

The economies of sub-Saharan African countries either declined or stagnated after the economic boom of the 1970s, due to the combination of the decline in commodity prices, institutional bottlenecks and civil unrest. In total, 28 African countries had already achieved their 1999 GDP level in earlier decades (World Development Report, 2003:18). For example, Angola (where civil war raged from the mid-1970s) had the same GDP per capita in 1999 as it had achieved before the 1960s. This shows that Angola's economy declined from the 1960 s to 1999 , despite its abundant mineral resources.

A direct result of the decline of the growth of African countries' economies is that the continent is the poorest in the world with an estimated one-third of its population (10\% of the world total) living below the poverty line. African nations, as economic entities have failed to deliver the expected results. Out of 41 heavily indebted poor countries (HIPC), 33 are from Africa (World Bank webpage-HIPC, 2008:29). In addition, the level of their debt represents more than four times their annual exports earnings, and exceeds their Gross National Products (GNP).

It is against this socio-economic background that a new breed of African leaders has come to the view that there is a necessity to design a more effective African initiative, which will be responsive to the pressing needs of the African people. The New Partnership for Africa's Development (NEPAD), formed in October 2001, is an initiative by African leaders to end misery across Africa and to launch its sustainable development. This article assesses the ways in which the transport sector can support and contribute to the successful implementation of NEPAD and the achievement of its objectives. 
A list of acronyms is given in Table 2.

Table 2: Acronyms

\begin{tabular}{|l|l|}
\hline ADB & African Development Bank \\
\hline AMU & Arab Maghreb Union \\
\hline ATS & Airport Transfer Service \\
\hline AU & African Union \\
\hline CBI & Cross-Border Initiatives \\
\hline COMESA & Common Market for Eastern and Southern Africa \\
\hline EAC & East African Community \\
\hline ECCAS & Economic Community of Central African States \\
\hline ECOWAS & Economic Community Of West African States \\
\hline EU & European Union \\
\hline FTA & Free Trade Area \\
\hline GDP & Gross Domestic Product \\
\hline GNP & Gross National Product \\
\hline HIPC & heavily indebted poor countries \\
\hline ICAO & International Civil Aviation Organisation \\
\hline IMF & International Monetary Fund \\
\hline IOC & Indian Ocean Commission \\
\hline IT & Information Technology \\
\hline NEPAD & New Partnership for Africa's Development \\
\hline PPPs & Public Private Partnerships \\
\hline RECs & Regional Economic Communities \\
\hline RPKs & revenue passenger kilometres \\
\hline SACU & Southern African Customs Union \\
\hline SADC & Southern African Development Community \\
\hline SSA & Sub-Saharan Africa \\
\hline TEN & Trans-European Network \\
\hline UNECA & UN Economic Commission for Africa \\
\hline & \\
\hline
\end{tabular}

\section{OVERVIEW OF NEPAD}

At the launch of NEPAD, its initiators hoped to provide an African initiative that, with the support of western countries, would assist in the renaissance of the continent. NEPAD intends to inspire political stability and address shortage in infrastructure, education and health. NEPAD's organisational structure comprises five task teams, responsible for developing plans in the following areas, each headed by an institution:

- Economic and corporate governance - UN Economic Commission for Africa (UNECA)

- Agriculture and market access - African Union (AU)

- Infrastructure - African Development Bank (ADB)

- Central bank and financial standards - African Development Bank (ADB)

- Capacity-building on peace and security - African Union (AU) 
NEPAD appeals to the people of Africa to regain confidence in their ability and capacity to overcome obstacles, and to be involved in the building of the new Africa despite the present difficulties (NEPAD, paragraph 53:8, 2001). One of NEPAD's sectoral priorities is to bridge the infrastructure gap: transport, energy, water and information/communication technologies.

Inadequate infrastructure is a critical obstacle to intra-African trade and to the competitiveness of African products in international markets. Transport can facilitate the flow of people, ideas and technology. It is also well documented that positive linkages exist between adequate transport infrastructure and economic development. An improvement in the transport system can help overcome bottlenecks in production and regional trade, thus fostering economic growth. Yet, Africa lags behind in all levels of transport infrastructure and systems.

\section{MAIN FINDINGS}

In assessing the role of the transport sector in the African renaissance, various challenges were scrutinised, which could make the sector responsive to the pressing need for development of the continent. The main findings include the inefficiency of transport operations, the role of the private sector in the financing of major infrastructure projects and overlapping membership in Regional Economic Communities (RECs).

\section{Inefficiencies of the transport sector}

Transport inefficiencies of Africa can be summarised in terms of the main modes.

\section{- Road}

In road transport, Sub-Saharan Africa has the lowest percentage of paved roads of all world regions. The average paved road-to-population ratio for the Southern African Development Community (SADC) region is $592 \mathrm{~km} / \mathrm{million}$ compared with $1335 \mathrm{~km} /$ million for middle-income countries and more than 10000 km/million for high-income countries (World Bank-SSATP paper No. 43). Roads in Africa are built in isolated short sections rather than in interconnected systems, and maintenance has been neglected resulting in a large backlog.

A review of 19 sub-Saharan African countries showed that between 1986 and 1988, 58 per cent of road expenditure was devoted to new construction or improvement, 17 per cent to rehabilitation, and only 25 per cent to routine maintenance (Heggie, 1995: 23). As a result, the backlog in road maintenance has increased the cost of road transport. Heggie (1995: 12) estimated that the extra cost of deferred maintenance was about US\$1.2 billion annually. 


\section{- Rail}

The map of Africa exhibits rail lines running from the interior to the coast, reflecting the reality of raw materials exported overseas.

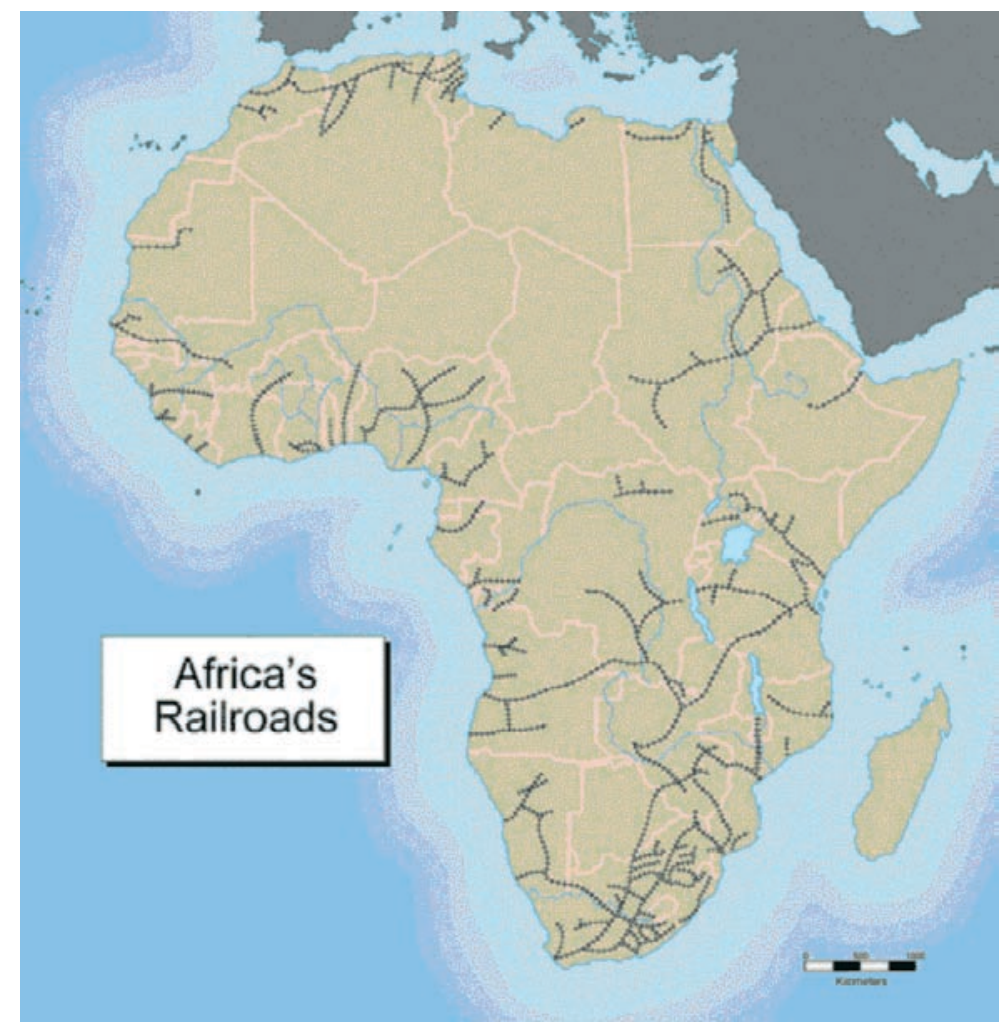

Source: Michigan State University, http://exploringafrica.matrix.msu.edu

Figure 1: The rail network in Africa

African railways have a low coverage of the continent. In terms of density (ratio of rail length per country's area), Africa accounts for about $3 \mathrm{~km} / 1000 \mathrm{~km} 2$, compared to $19 \mathrm{~km} / 1000 \mathrm{~km} 2$ and $24.9 \mathrm{~km} / 1000 \mathrm{~km} 2$ for India and the USA respectively (CIA World Fact Book, 2000 More than seven track gauges exist, implying the necessity for transshipment at certain places. Also on African rail systems, freight rates are on average about twice as high as those in Asia and one-and-a-half times those in Latin America (Amoako, 1997: 4).

\section{- Air}

The African air industry suffers from missing intra-African connections, high operating costs and tariffs, weak demand, remoteness from major markets, a limited pool of trained staff, and unnecessary government involvement. Africa represented $2.6 \%$ of the world air traffic in 2000 (revenue passenger kilometres [RPKs]), compared with 14\% for the intra-Asian air traffic (Airbus, 2002). 


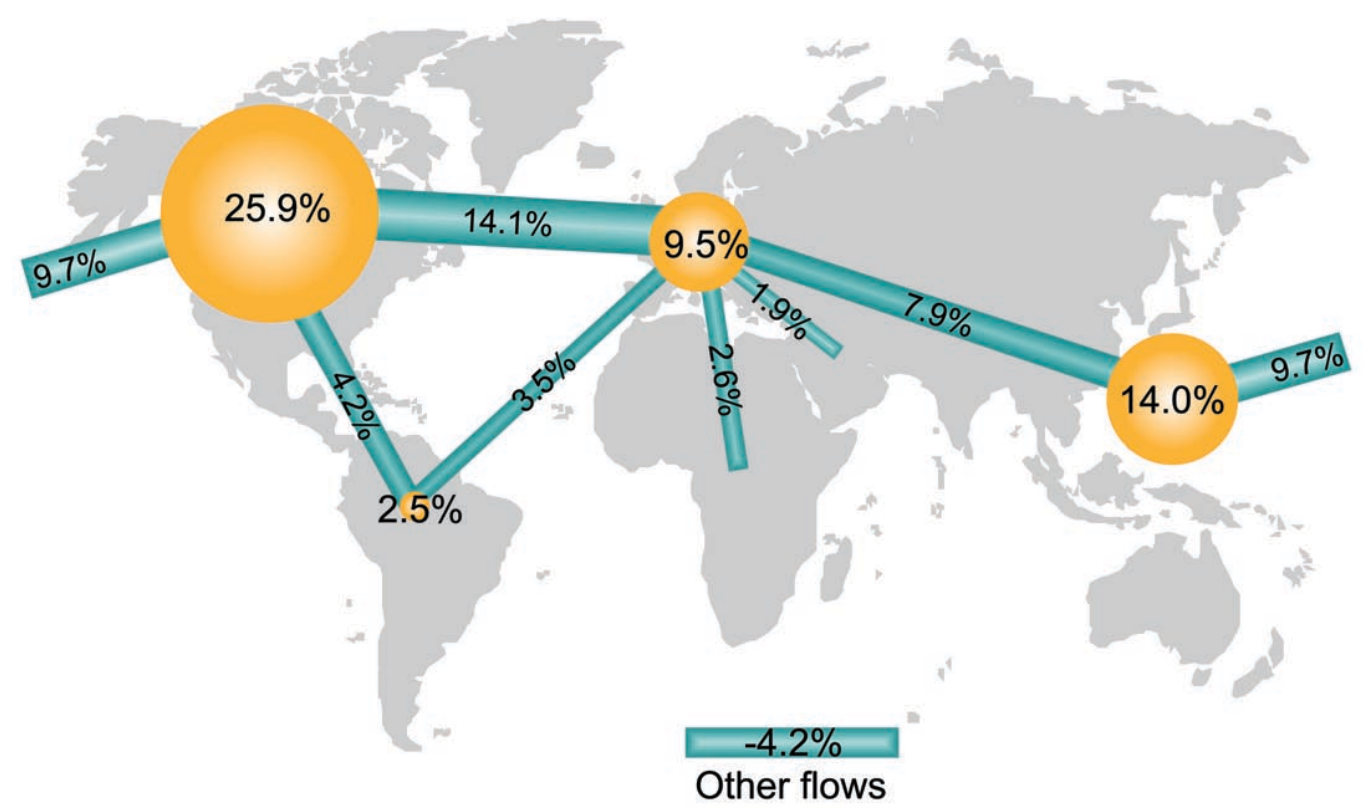

Source: Airbus, 2002, p22.

Figure 2: Major international flows between regions (RPKs, 2000)

In 1988, the Yamoussoukro Declaration intended to open up the aviation industry on the continent and facilitate better air services. However, many states are still overprotective of their airlines and are reluctant to allow fellow African airlines to compete on their routes.

\section{- Maritime}

In maritime transport, the lack of investment to increase port capacity, combined with poor management of port operations, have resulted in bottlenecks in traffic flows. Africa has yet to keep pace with the worldwide trend for increased containerisation and the development of cellular ships. In 1997, Africa represented only $2.0 \%$ of the world total container traffic compared with $48.1 \%$ for Asia (Drewery, 1998; quoted by Chia, Onyirimba \& Akpan: 1999). In terms of TEUs capacity of fully cellular container ships, the African share in 2002 stood at 10674 TEUs or $0.2 \%$ of the world total compared to Asia at 13.2\% (UNCTAD, 2001: 19). The freight factor costs of imports to African countries in 1998 were $11 \%$ of the total value of imports, compared to $8 \%$ for developing economies and $4 \%$ for developed countries (UNCTAD, 1999: 3).

In this regard, many challenges lie ahead of NEPAD in addressing the poor socio-economic performance of Africa, including the transport sector. Although an efficient transport system by itself is unlikely to stimulate economic activity, an adequate transport infrastructure and policy framework can facilitate exports and intra-regional trade, thus fostering economic growth.

Bridging the transport infrastructure gap can therefore be an important factor in unlocking the human and economic potential of the continent. NEPAD aims to coordinate and channel regionally fragmented efforts into one core long-term vision for the continent. However, this praiseworthy goal is overshadowed by the multiplicity of regional agreements and overlapping membership. 


\section{Multiplicity of RECs and overlapping membership}

This section compares the situation in Africa with that of the European Union (EU).

\section{Africa}

More than 14 RECs exist in Africa, leading to the duplication of functions, complex institutional arrangements and the difficulty in the coordination of policies (different objectives and timetables). Figure 1 shows the existence of six RECs in eastern and southern Africa, namely: Southern African Development Community (SADC), Common Market for Eastern and Southern Africa (COMESA), Southern African Customs Union (SACU), Cross-Border Initiatives (CBI), Indian Ocean Commission (IOC) and East African Community (EAC).

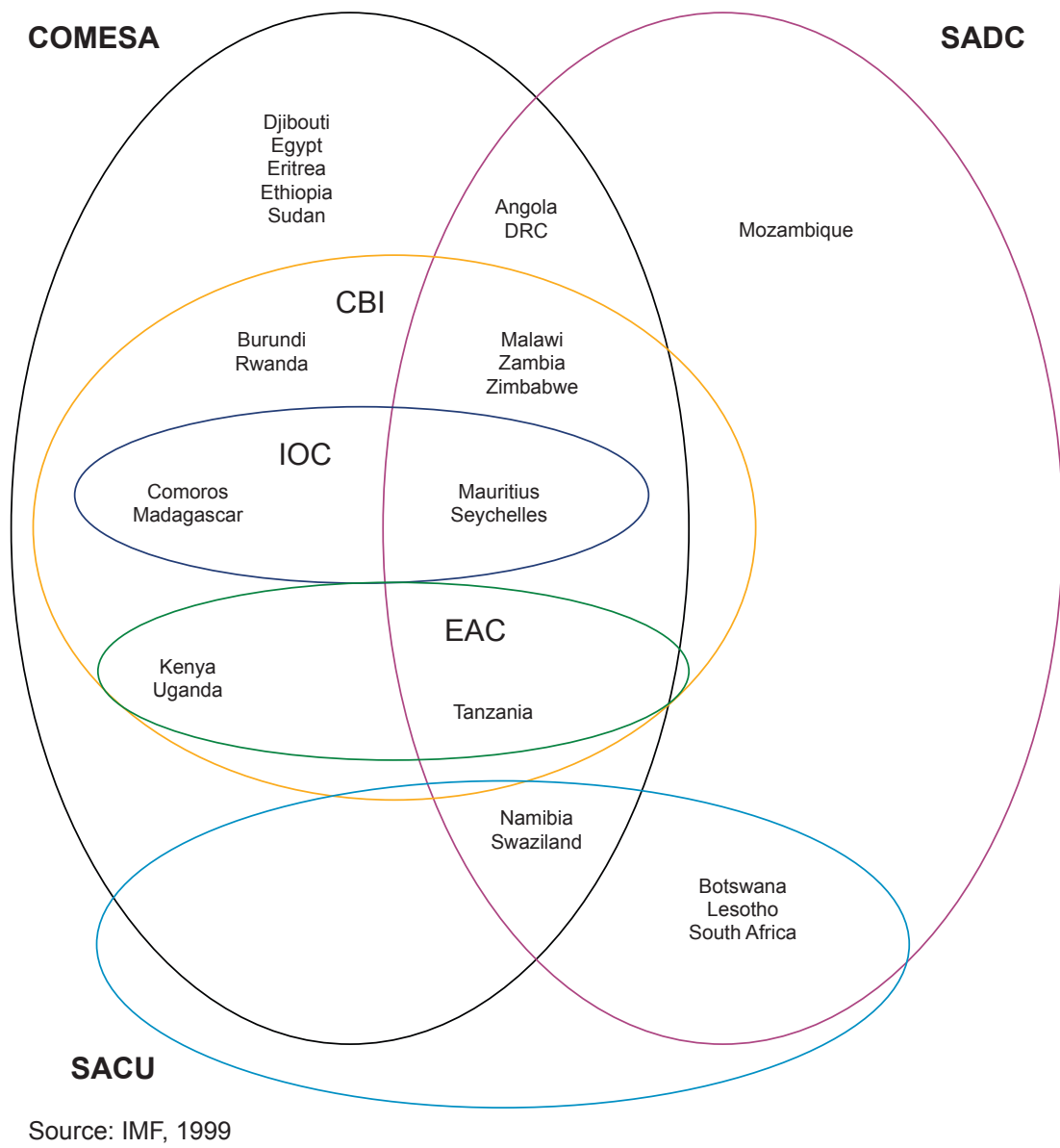

Quoted by Fajgenbaum, Sharer, Thugge \& DeZoysa, 1999:12

Figure 3: Southern and Eastern Africa overlapping regional arrangements

From Figure 3, it can be seen that many countries belong to more than one REC. This overlapping membership leads to the duplication of activities, increased financial and human costs and difficulty in the coordination of timetables.

In Table 3, the analysis of the transport strategies of the SADC and COMESA reveal differences in the prioritisation of objectives and often reflect the type of economic integration chosen by the region. 
Table 3: Comparative analysis between SADC and COMESA transport strategies

\begin{tabular}{|c|c|c|}
\hline & SADC & COMESA \\
\hline Objective & $\begin{array}{l}\text { - Attain sustainable growth of the } \\
\text { member states } \\
\text { - Promote joint development in all } \\
\text { - Cields of economic activity } \\
\text { - Cooperate in the creation of an } \\
\text { enabling environment for foreign, } \\
\text { cross-border and domestic } \\
\text { investment } \\
\text { - Cooperate in the promotion } \\
\text { of peace, security and stability } \\
\text { among member states } \\
\text { - Cooperate in strengthening the } \\
\text { relations between COMESA and } \\
\text { the rest of the world } \\
\text { - Contribute towards the } \\
\text { establishment, progress and } \\
\text { realisation of the objectives of the } \\
\text { African economic community }\end{array}$ & $\begin{array}{l}\text { - Achieve development and } \\
\text { economic growth, alleviate } \\
\text { poverty, enhance the quality of } \\
\text { life of the people of southern } \\
\text { Africa and support the socially } \\
\text { disadvantaged through regional } \\
\text { integration } \\
\text { - Deeper economic cooperation } \\
\text { and integration } \\
\text { - Common economic, political, } \\
\text { social values and systems, } \\
\text { democracy and good governance, } \\
\text { respect for the rules of law and the } \\
\text { guarantee of human rights } \\
\text { - Regional solidarity, peace and } \\
\text { security }\end{array}$ \\
\hline Vision & $\begin{array}{l}\text { - Efficient, cost-effective and fully } \\
\text { integrated infrastructure and } \\
\text { operations, which best meet the } \\
\text { needs of customers and promote } \\
\text { economic and social development } \\
\text { while being environmentally and } \\
\text { economically sustainable }\end{array}$ & $\begin{array}{l}\text { - Provide a coordinated and } \\
\text { complementary transport policy, } \\
\text { quality transport infrastructure } \\
\text { and services that support the } \\
\text { overall goal of the region for } \\
\text { full economic cooperation and } \\
\text { integration }\end{array}$ \\
\hline $\begin{array}{l}\text { Integrated } \\
\text { transport }\end{array}$ & $\begin{array}{l}\text { - Efficiency and reliability of all } \\
\text { individual parts of the transport } \\
\text { chain } \\
\text { - Modal choice and development of } \\
\text { multimodal service provision } \\
\text { - Specific bilateral agreements } \\
\text { between member states for transit } \\
\text { rights } \\
\text { - Transport infrastructure and } \\
\text { services progressively self- } \\
\text { sustained with funding based on a } \\
\text { user pay principle } \\
\text { - Multimodal corridors will } \\
\text { encourage cooperation between } \\
\text { governments, parastatals and } \\
\text { private sector }\end{array}$ & $\begin{array}{l}\text { - Harmonise and simplify } \\
\text { regulations, procedures and } \\
\text { documentation required for } \\
\text { multimodal inter-state transport } \\
\text { - Provide, where feasible, technical } \\
\text { facilities for direct trans-shipment } \\
\text { of goods at main trans-shipment } \\
\text { points } \\
\text { - Ratify international conventions } \\
\text { on multimodal transport and } \\
\text { containerisation }\end{array}$ \\
\hline
\end{tabular}




\begin{tabular}{|c|c|c|}
\hline $\begin{array}{l}\text { Road } \\
\text { transport }\end{array}$ & $\begin{array}{l}\text { - Liberalisation of road freight and } \\
\text { passenger transport } \\
\text { - Enhancement of competition, } \\
\text { multilateral agreements, removal } \\
\text { of quotas on intra-regional } \\
\text { movement } \\
\text { - Harmonisation of administrative } \\
\text { procedures } \\
\text { - Harmonisation of transport law } \\
\text { enforcement } \\
\text { - Standardisation of national } \\
\text { legislation on relevant road traffic } \\
\text { including driving licences, fitness } \\
\text { of vehicles, loads on vehicles and } \\
\text { transportation of abnormal and } \\
\text { hazardous loads } \\
\text { - Promotion of the involvement of } \\
\text { the private sector, road users, local } \\
\text { authorities, financial institutions } \\
\text { and environmental interest } \\
\text { groups in the planning, design, } \\
\text { construction, maintenance, } \\
\text { operation and financing of roads }\end{array}$ & $\begin{array}{l}\text { - Gradual reduction and eventual } \\
\text { elimination of all non-physical } \\
\text { barriers to road transport within } \\
\text { the common market } \\
\text { - Making road transport efficient } \\
\text { and cost effective by promoting } \\
\text { competition and facilitating road } \\
\text { haulage industry operations } \\
\text { - Harmonisation of transport } \\
\text { policies and adoption of common } \\
\text { regulations for safety, insurance, } \\
\text { vehicles fitness, transport of } \\
\text { special goods, etc. } \\
\text { - Maintaining, rehabilitating, } \\
\text { upgrading and reconstructing the } \\
\text { inter-state trunk road projects } \\
\text { - Harmonisation of road transit } \\
\text { charges }\end{array}$ \\
\hline $\begin{array}{l}\text { Civil } \\
\text { aviation }\end{array}$ & $\begin{array}{l}\text { - Gradual liberalisation of intra- } \\
\text { regional air transport for local } \\
\text { airlines } \\
\text { - Progressive commercialisation of } \\
\text { SADC airlines and airports } \\
\text { - Common business objectives } \\
\text { and harmonisation of technical } \\
\text { standards } \\
\text { - Compliance to International Civil } \\
\text { Aviation Organization (ICAO) } \\
\text { standards } \\
\text { - Human resource development }\end{array}$ & $\begin{array}{l}\text { - Liberalisation of air transport } \\
\text { services with a view to increasing } \\
\text { the efficiency and profitability of } \\
\text { the industry } \\
\text { - Adoption of common policies } \\
\text { for the development of air } \\
\text { transport in the common market in } \\
\text { collaboration with the ICAO } \\
\text { - Making air transport services } \\
\text { more efficient and profitable } \\
\text { through, interlaid, autonomous } \\
\text { management } \\
\text { - Harmonisation of civil aviation } \\
\text { rules and regulations } \\
\text { - Establishment of common } \\
\text { measures for the facilitation of } \\
\text { passenger and cargo air services } \\
\text { - Agreement to charge the same } \\
\text { rates and apply the same rules } \\
\text { and regulations relating to } \\
\text { scheduled air transport services } \\
\text { among themselves } \\
\text { - Development, maintenance } \\
\text { and coordination of common, } \\
\text { regional airlines' navigational } \\
\text { communications and } \\
\text { meteorological facilities for the } \\
\text { provision of safe air navigation } \\
\text { - Agreement on common technical } \\
\text { standards } \\
\text { - Implementation of CNS/ATM } \\
\text { systems }\end{array}$ \\
\hline
\end{tabular}

Source: Compiled from the SADC and COMESA treaties 
SADC emphasises the need for privatisation and concessioning of transport operations. In contrast, COMESA advocates restructuring and liberalisation, with the aim of developing a sustainable transport sector, directed towards the establishment of an economic union. The process for the creation of the free trade area includes the total elimination of tariffs on products from member countries and the removal of non-tariff barriers such as export quotas, easing of customs procedures and coordination of border crossings. It is obviously difficult for member countries of COMESA, subject to the free trade area (FTA) rules, to accommodate SADC obligations. Although policies may be similar, technical specifications such as maximum vehicle load requirements differ.

A similar situation prevails in the air transport industry, where the COMESA air transport regulatory board has set the conditions for market access, airline alliances, cross-border investments by member states, and technical, safety and security issues. The road map to the creation of a COMESA "single sky" follows two phases. Phase 1 aims to:

- eliminate capacity and equipment restrictions

- facilitate free movement of cargo and non-scheduled passenger services

- provide free movement of intra-regional scheduled passenger services with frequency limits of up to two daily between cities

- grant fifth freedom traffic rights on specific routes.

Following the initial step, Phase 2 provides for free movement of intra-regional air transport services and establishes the COMESA air transport regulatory board. The implementation of these major changes has facilitated cooperation through code-sharing agreements, an increase of flight frequencies between city pairs, a reduction in fares, better customer services and an increase in revenue collection by airports and airport transfer service (ATS) providers (Marawa, 2003: 4).

These examples underline the difficulty for countries belonging to several regional agreements to implement adopted policies. Adding to the confusion, the laws of individual countries are diverse, thus resulting in misinterpretation of strategies. In intra-regional trade, it is well documented that the "rule of origins" that provides for tax exemption according to the origin of products, is a challenge to the achievement of a free trade area. It is often difficult to clarify the initial origin of products while they are within the integrated market.

\section{European Union (EU)}

The foregoing is sharply in contrast with the EU, which promotes, in the transport sector for example, a unique strategy that supports a single vision for the development of Europe. The key objectives of the EU in the transport sector are to harmonise transport regulations, to be responsive to the economic development of Europe and to create an efficient transport system that is environmental friendly. Table 4 compares the EU White Paper on transport policy with regional African transport strategies.

It can be seen from the table that a number of areas are addressed in EU actions while it is not yet contained in the actions of various trade blocks. It should however be borne in mind that the existence of such trade blocks have been more recent if compared to EU. 


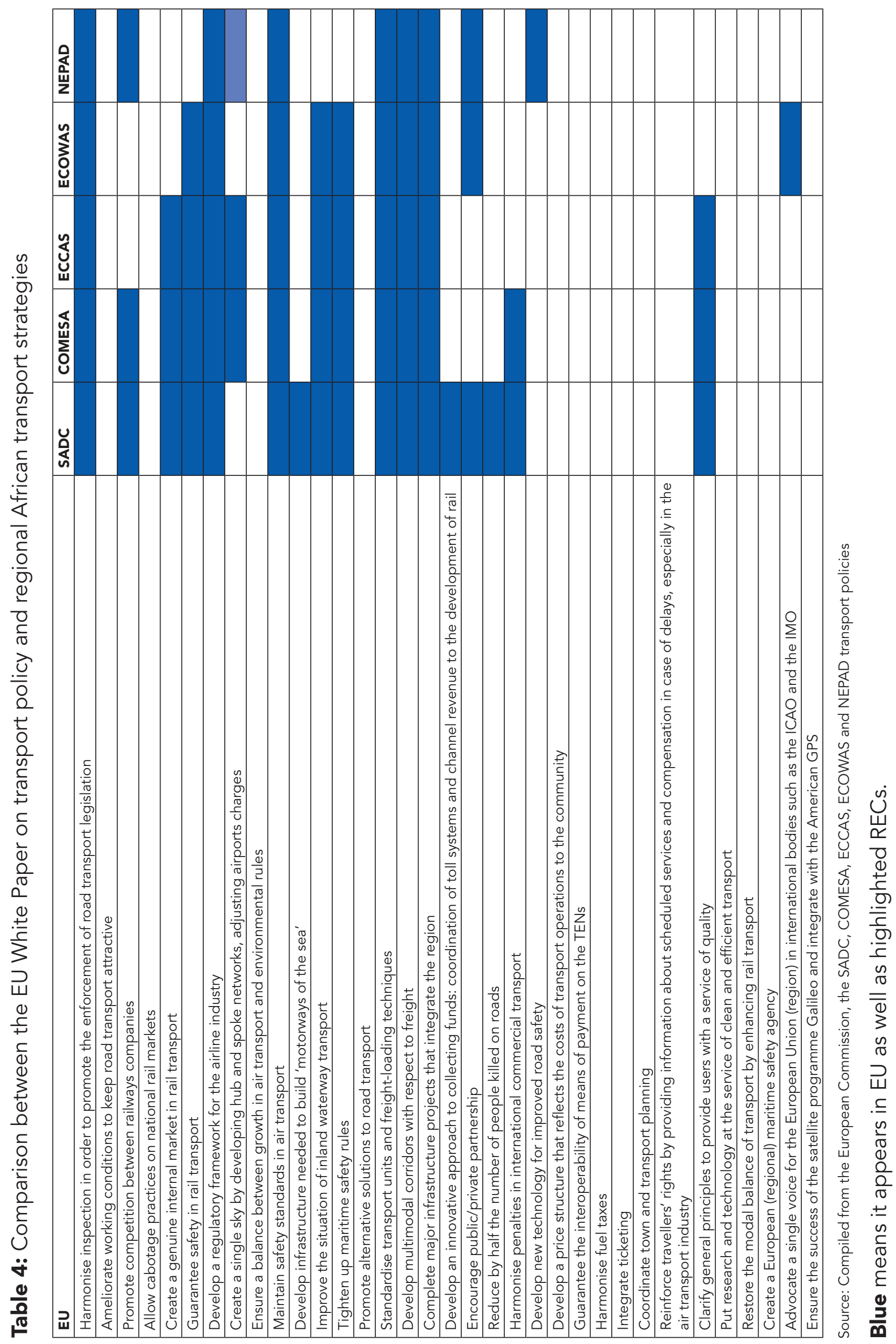


The EU has also identified the main transport infrastructure projects necessary to link the continent and to unlock the economic potential of regions. These main arteries, called the trans-European network (TEN), are the focus of investment from the EU Commission, with the feeder network being the responsibility of individual countries. Bearing in mind the differences between NEPAD and the EU transport strategies, the problem is to adjust the African initiative in a way that incorporates the best overseas practices.

\section{The private sector}

One important challenge for Africa is to establish a favourable climate for investment. In 1999, privatisation projects in sub-Saharan Africa amounted to only US\$694 million compared with US\$23.6 billion for Latin America and the Caribbean, and US\$10.3 billion for Eastern Europe and Central Asia (World Bank, 2001: 184-187). Increasingly in Africa, the private sector is involved in transport management and provision. However, large parastatals are still subject to political interference and corruption. As a result, the transport sector is still characterised by the inefficiency of service and the shortage of revenue to maintain infrastructure and sustain investment.

\section{SUMMARY OF THE MAIN FINDINGS}

NEPAD cannot work if there is too much high level strategic regional focus with little involvement of civil society, specific requirements and needs of African countries, and the private sector. NEPAD's current strategy of keeping a facilitating role while RECs are in charge of implementing programmes, is likely to produce sub-optimal outcomes. In general, RECs lack political will, expertise, funds, and institutional arrangements to execute most of the actions efficiently.

Researchers, increasingly, are of the opinion that there is a need to change the direction of NEPAD, in the implementation of its programmes. Herbert (2004) argued that the NEPAD secretariat should become a high-powered continental think-tank that is capable of developing the key tactical steps necessary in each sector to achieve sustainable economic growth on the continent. Moreover a timetable for the implementation of policies is necessary. NEPAD should develop some general high-level objectives and strategies related to transport operations and infrastructure. These include:

- Reduce the current plethora of RECs to five: SADC, COMESA, Economic Community of Central African States (ECCAS), Economic Community Of West African States (ECOWAS) and Arab Maghreb Union (AMU). In addition their structure should be rationalised and aligned according to a single continental vision.

- Progressively put an end to overlapping membership and the development of special arrangements through NEPAD, for countries with specific interests. 
- Simplify and harmonise transport regulations in order to standardise operations and establish a common key performance measurement.

- Simplify procedures and systems at borders to enhance trade between various countries.

- Define each country's competitive advantage in all economic sectors and develop continental transport strategies based on these strengths.

- Make the private sector a driving force by developing Public Private Partnerships (PPPs) in order to ensure the economic sustainability of transport operations and cross-border investments.

- Embark on investment strategies to link up the various railway systems in operation on the continent.

- Develop financing mechanisms through the World Bank, the International Monetary Fund (IMF), the ADB, etc., for key infrastructure projects that will economically link the continent.

- Deregulate the air industry and implement the Yamoussoukro decisions, with a view to modifying market forces, increasing competition and liberalising access to air transport markets in Africa.

- Embark on information technology (IT) and communication systems that foster innovation and improved customer service.

- Focus investments on transport corridors (road or rail) that link major ports to the African hinterland and landlocked countries, in order to sustain existing corridors of development and create new ones. This could also entail programmes to repair and maintain present road infrastructure and port infrastructure already in existence.

- Develop a reliable database on African transport operations.

- Ameliorate working conditions in the transport industry (drivers, traffic officials, employees, etc.).

- Train personnel and build capacity to ensure the presence in the transport sector of managerial skills (policy, operations, projects, etc.), financial expertise and technical capabilities.

- Assess the social and environmental impacts of transport operations.

It should also be kept in mind that no quick-fix solutions exist to solve the problems of Africa. Only a sustainable continental vision developed for the long term, with the support of the people of Africa can yield better prospects for future generations. 


\section{REFERENCES}

Airbus. 2002. Global market forecast. Airbus S.A.S. France. Available online at: www.airbus. $\mathrm{com} / \mathrm{pdf} / \mathrm{media} / \mathrm{gmf2001}$.pdf

African Development Bank (ADB). 2003. NEPAD Infrastructure short-term Action Plan. Review of Implementation Progress and the Way forward. Volume 1: Overview.

African Union (AU). Regional Economic Communities. www.africa-union.org

Amoako, K.Y. 1997. At the eleventh Conference of Ministers of Transport and Communications and First Forum on Transport in Africa (FTA). United Nations Economic Commission for Africa.

Boeing. 2003. Current market outlook. Boeing commercial Airplanes/Marketing.

Braga de Macedo, J. \& Kabbaj, O. 2002. Regional Integration in Africa. OECD-AFDB/ International Development.

Brennan, S. Trans European Transport Network "A major step forward for the enlarged Europe". Policy area: Transport, Telecommunications and Energy. Press releases. Available online at: www.eu2004.ie/templates/news.asp?sNavlocator=66\&list_id=579

CIA World Fact Book, 2000: https://www.cia.gov/library/publications/the-world-factbook/

Chia, L.S., Onyirimba L.C \& Akpan, G.S. 1999. Liberalization of maritime transport services: Directions and options for Asia. National University of Singapore. Available online at: www1. worldbank.org/wbiep/trade/manila/maritime.pdf

Clare Short, A. 2002. NEPAD: We must focus on Africa's Development. British Secretary of State for International Development. Mail \& Guardian (April 19, 2002). Available online at: www.web.net/ iccaf/debtsap/nepadbritish.htm

Department of Foreign Affairs. 2001. NEPAD Communiqué. Available online at: www.dfa. gov.za /docs/nepad.htm

Economic Commission for Africa. 2002. Annual report on integration in Africa 2002 Overview.

EU Presidency 2004 website: EU Transport Policy. Available online at: www.eu2004.ie 
Europa. 2004. The EU at a glance - The History of the European Union. Available online at: www.Europa.eu.int

The World Bank Group, The New Anticorruption Home Page. Available [Online] At: Fontaine, P. 2003: Europe in 12 Lessons. The European Commission, 2003.

Geda, A. \& Kibret, H. 2002. Regional economic integration in Africa: a review of problems and prospects with a case study of COMESA. Available [online] at: http://mercury.soas. ac.uk/economics/workpap/abobe/wp125.pdf

Heggie, lan G. 1995. Management and Financing of Roads, an Agenda for Reform. SSATP Working Paper No. 275, World Bank.

Herbert, R. June 2002. Implementing NEPAD, a Critical Assessment. Africa Research Fellow. South African Institute of International Affairs.

Institute for Security Studies (ISS). 2004. African Regional Organisations. From Unity to Union. Available online at: www.iss.co.za/AF/RegOrg/unity_to_union/main.html

Marawa, A. 2003. The COMESA air transport liberalization experience. ICAO headquarters, Montreal-Canada. Available online at:

www.icao.int/icao/en/atb/atconf5/Seminar/Marawa.pdf

Michigan State University. 2002. Module Nine, Unit two: Studying Africa through the social studies. Activity Five: Transportation in Colonial Era: the movement of goods and People, http://exploringafrica.matrix.msu.edu.

NEPAD Framework Document. Online at www.nepad.org.

SADC Transport Policy. Online at http://www.transport.gov.za/library/docs/misc/sadc.html.

SADC Treaty. Online at http://epa.tralac.org/scripts/content.php?id=439.

Schiff, M. \& Winters, A.L. 2003. Regional Integration \& Development. World Bank. Oxford University Press.

Sylte, Kr. 1999. Improving Management and Financing of Roads in Central African States. Africa Transport. Technical Note no.22.

Sylte, Kr. 1999. Review of the Road sector in Customs and economic Union of Central African States (UDEAC). SSATP Working Paper No. 43, World Bank. 
The Economic Commission for Africa (ECA). 2003. Progress Report on the Implementation of the Yamoussoukro Declaration on a New African Air Transport Policy. Available online at:

www.uneca.org/eca_resources/Publications/RCD/old/a_new_african_transport_policy

The European Commission: Towards sustainable transport infrastructure: A sectoral approach in practice. Available online at: www.europa.eu.int

The European Commission. 2001. White Paper, European Transport Policy for 2010: time to decide.

The European Commission. 2001. Transport web page. Available online at: http://europa. eu.int

The New Partnership for Africa's Development (NEPAD): October 2001. Online at https:// www.cia.gov/library/publications/the-world-factbook/

The World Bank Group. 2001. Global Development Finance. Building Coalitions for effective development finance: Appendix 4. Available online at:

www.worldbank.org/prospects/gdf2001/vol1htm

The World Bank Group. Private participation in Infrastructure. Available online at: http://rru. worldbank.org/book/Chapter7.pdf

United Nations Conference on Trade and Development (UNCTAD). 1999. Foreign Direct Investment in Africa: Performance and potential United Nations - New York and Geneva, 1999.

UNCTAD. 2001. Economic development in Africa: performance, prospects and policy issues. United Nations - New York and Geneva.

United Nations Economic Commission for Africa (UNECA). April 2001. Compact for African Recovery. Operationalising the Millennium Partnership for the African Recovery, Addis Ababa.

United Nations Economic Commission for Africa (UNECA). 2002. Annual Report on integration in Africa - Overview. Addis Ababa.

University of Bristol-Institute for Learning and Research Technology. 2004. Learning material. The European Union. Available online at: www.bized.ac.za 
Walters, J. 1998. The role of Transportation in the African Renaissance. R.A.U. Available online at: http://general.rau.ac.za/aambeeld/november1998/transportation.html

World Bank Group - World Development Report, 2003: Online at: http://go.worldbank. org/UANNFG43T0

World Bank webpage-HIPC, 2008:29. Online at: http://www.imf.org/external/np/exr/facts/ hipc.htm\#P29 4350

World Bank-SSATP paper no 43. Online at: http://extsearch.worldbank.org/servlet/SiteSea rchServlet?q=SSATP\%20paper\%20no\%2043 